\title{
A Study of the Direct Costs of Anesthesiology and Reanimatology in Clinical Center Serbia
}

\author{
Branislava M. Majstorović ${ }^{1}$, Branko D. Milaković1,6, \\ Tamara S. Naumović 2 , Zoran M. Bukumirićc , Srdjan Z. Marković ${ }^{4}$, \\ Dragana A. Kastratović ${ }^{4}$, Ivan D. Vukašinović ${ }^{5}$, Nebojša G. Ladjević ${ }^{1,6}$ \\ ${ }^{1}$ Center for Anesthesiology and Reanimatology, Clinical Center of Serbia, Belgrade, Serbia \\ ${ }^{2}$ Institute of Public Health of Serbia "Dr Milan Jovanović Batut", Belgrade, Serbia \\ ${ }^{3}$ Institute for Medical Statistics and Informatics, Faculty of Medicine, University of Belgrade, \\ Belgrade, Serbia \\ ${ }^{4}$ Clinical Centre of Serbia, Belgrade, Serbia \\ ${ }^{5}$ Cabinet for intervention and invasive neuroradiology, Center for radiology and magnetic reso- \\ nance, Clinical Center of Serbia, Belgrade, Serbia \\ ${ }^{6}$ Medical Faculty University of Belgrade, Belgrade, Serbia
}

\section{SUMMARY}

Introduction: Modern health care implies the continuous development of human resources and the application of pharmacoeconomic analyzes during the introduction of new methods of treatment in medicine.

Aim: The aim of the paper is to compare and analyze: 1) the number of: operated patients, provided anesthesia services, hospital days in ICU and surgery interventions; 2) distribution of anesthetic services: general anesthesia, local anesthesia and anesthesia procedures and 3) the values of direct costs of anesthesiology and reanimatology , in 2006 and 2015 in order to propose measures of rationalization and savings of funds.

Methods: This paper is part of an academic IV phase study, conducted at the Clinical Center of Serbia (CCS) with the permission of the Ethical Committee of the Medical Faculty of the University of Belgrade (470 / IV7) and harmonized with the European Union Directive. Direct costs of anesthesiological services of the Center for Anesthesiology and Reanimatology, by department of anesthesia in the maternal surgical clinics of the Clinical Center of Serbia in Belgrade, during 2006 and 2015, are included and analyzed. The subjects were all anesthetized patients, both sexes, children and adults. The numeric data is processed by Microsoft Office Excel 2003 and SPSS for Windows. For the analysis of the statistical significance of the number of patients, anesthesiologic services, hospital days in Intensive Care Units and surgical procedures was used Wilcox test.In order to analyze the percentage distribution of funds in the category of direct costs (personal costs, drugs, materials, analyzes and medical equipment), in 2015 compared to 2006 was used the hi-square matching test.

Results: There is a statistically significant difference in the frequency of service categories within the scope of services in 2015 compared to 2006 ( $p<0.001$ ), indicators of hospital work. 
There is a statistically significant difference in the frequency of anesthetic services in 2015 compared to 2006 ( $p<0.001)$.

There is a statistically significant difference in the total direct cost of anesthesiology and reanimatology between 2006 and $2015(p=0.043)$. There is a statistically significant difference in the frequency of direct cost categories in 2015 relative to 2006 ( $p$ $<0.001$ ).

In the period of recession and transition in $2006,42 \%$ of funds for personal expenses were separated, for medicines and materials $29 \%$, analyzes and medical devices $29 \%$. The direct costs of anesthetic services would be at the annual level of $10 \%$ relative to the means of surgical activity. Without taking into account methodological concerns (organizational changes, introduction of new groups of drugs in the responsibility of anesthesiologists, limiting legal regulations, higher prices), after a ten-year period, the ratio of direct costs was changed in 2015 , so that personal costs amount to $4 \%$, drugs and materials amount to $94 \%$ and analysis and medical equipment amount to $2 \%$.

Conclusion: 1. The 10-fold decrease in personnel costs in 2015 statistics is certainly not a consequence of a change in the methodology, but a constant, chronic and progressive impairment of vocational work in total health care costs. 2. Anesthetist services are only visible during their stay in the operating room. It is evident that most of the services performed in: preoperative assessment and preparation, immediate postoperative and delayed, chronic treatment of critical patients, are either unrecognized or incorrectly attributed to surgical specialties. 3. The quality of the statistical data presented is indicating the lack of interest of the hospital administration in analyzing and utilizing the collected data in reducing and rationalizing health care costs. 4. Academic multicenter studies in pharmacoeconomics are needed to help doctors to achieve a better uniform standards of providing anesthesia services using evidence based medicine.

Keywords: anesthesiology and reanimatology, hospital pharmacology, pharmacoeccomia, direct costs

\section{INTRODUCTION}

The complexity of the social environment accelerates the advancement of knowledge of technology, informatics and a unified global economy, in conditions of social diversity, population migration, ecological crisis and other global trends that will grow into an even more complicated world.

Progress in medicine is measurable through better therapeutic outcomes, by extending the duration of disease remissions and a better quality of life for residents in economically more developed countries. Economically underdeveloped countries cannot finance new methods of prevention, diagnostics, therapy and care in their health care systems. The ratio of health and population health is not in linear correlation [1]. The need to increase funds allocated for health care and the constant pressure of the administration for the rationalization and savings of funds are out of step.
Modern health care implies the continuous development of human resources and the application of pharmacoeconomic analyzes during the introduction of new methods of treatment in medicine. New technologies have been introduced in biochemical, hematological, microbiological, clinical-pharmacological and other laboratories. The industry is progressing alongside the development of medical knowledge, such as imaging technologies (computerized technology (CT), nuclear magnetic resonance (NMR), gamma knife (GK)), 3D technology and more [2]. Genetic diagnoses, tests and therapies, and especially vaccines, are increasingly represented in the treatment of tumors and infectious diseases. Prenatal surgery is under development, and diagnostic and therapeutic endoscopic surgical procedures are standardized for decades. Treatment with stem cells, as well as organ transplantation, are 
everyday surgical treatments. New methods of treatment increase the cost of health services on the one hand, but on the other, reduce the average length of hospitalization and the possible number of surgical reinterventions. The attitude of doctors and patients has changed through a rational and personalized approach to the patient. A health professional is not only a doctor, but also a teacher, a partner and a supervisor to his patients, helping them with the treatment and control of the disease.

Studies are underway to monitor vital parameters, such as the pacemaker's work, respiratory rate, etc. by remote sensor technology (medical softwares and smartphones), that could be corrected. All of the above, requires change and customization of the health care system in "smart healthcare system", considering the economic possibilities of the state, in the way of maximum effects within financial possibilities [3].

Anesthesiology and Reanimatology participate in diagnostics and therapeutic medical procedures for almost all diseases, primarily surgical treatments of patients, but also in healthy persons (aesthetic surgery), but in fact not treat any disease. Based on the primal human need to alleviate or completely abolish the pain of illness and surgery, it has evolved into a strong independent specialist field of specific principles for any surgical discipline. Today, anesthesia, intensive care Unit (ICU) and pain therapy are directions in which anesthesiology develops. Anesthesia has costs and outcomes. Expenses, however small, are collectively large. In foreign literature we found that the average cost of general anesthetic was from 6.00 to 8.08 euros for surgical interventions of 6.6 to 31.9 minutes in daily surgery, or 13 penny per minute of anesthesia, for patients of $70 \mathrm{~kg}$, which were compared with the price of a telephone conversation in Norway [4].

\section{AIM}

The aim of the paper is to compare and analyze:

1) the number of: operated patients, provided anesthesia services, hospital days in ICU and surgery interventions;

2) distribution of anesthetic services: general anesthesia, local anesthesia and anesthesia procedures and

3) the values of direct costs of anesthesiology and reanimatology, in 2006 and 2015 in order to propose measures of rationalization and savings of funds.

\section{METHODS}

This is an academic retrospective study of the IV phase cross-section, conducted at the Clinical Center of Serbia (CCS) with the permission of the Ethical Committee of the Medical Faculty of the University of Belgrade (470 / IV7) and harmonized with the European Union Directive [5]. It shows the direct costs of anesthetic services in 2006 and 2015, which are calculated for each anesthetized patient treated in the local surgical clinics CCS in Belgrade.

The data were collected from the database of CCS: Center for Anesthesiology and Reanimatology; Services for Organization, Planning, Social Medicine, Business Economics and Medical Informatics; Center for Social Medicine and Medical Statistics; Services for Economic and Financial Affairs; Services for Clinical Pharmacology; Services for Pharmacy supplies.

Consideration was given to limiting existing data in Serbia, the inconsistency of statistical data, so that available data on surgical costs at the CCS level were used, as needed, from the project of the European Union and the Ministry of Health of the Republic of Serbia, calculated for the reconstruction of Clinical Centers in Serbia [6]. General indicators of anesthetic and surgical services have been taken from the published results of the study and the Information on the work of surgical services of the Clinical Center of Serbia, published on the website KCS in 2015[7].

The effectiveness and quality of hospital work are measured by general indicators: the number of surgical beds, the extent of hospital treatment, the average length of stay of the treated patients in the parent surgical clinics and the use of beds[8]. The extent of the patient's treatment includes the number of patients undergoing surgery, the number of anesthetic services, the number of days in the Intensive Care Units and the number of surgical interventions. The general indicators are the basis for financial accounts.

Wilcoxon's test was used to analyze the difference in service volume between 2006 and 2015. For the analysis of the percentage distribution of the category of costs in 2015 compared to 2006 was used the hi-square 
matching test. Statistical hypotheses were tested at the statistical significance level of 0.05 . All data was processed in IBM SPSS Statistics 22 (SPSS Inc., Chicago, IL, USA) software package.

Serbia is a medium-sized country in which health care system is moving towards a Mix model of health insurance, where, in addition to compulsory health insurance most of its residents gradually introduce elements of a market model such as private health insurance, prospective savings, funding with local funds and donor help, with dominant state control of medical equipment and facilities.

The Republican Health Insurance Fund (RHIF) is the dominant entity that gathers funds and makes payments to health care providers. Anesthetic services are fiscally separated into three groups. In the first group, there are different types of general anesthesia. In the second group there are different techniques of local anesthesia.In the third group there are anesthetic procedures: analgesia, sedation, analgesia, short-term intravenous anesthesia (TIVA), controlled hypotension in ICU;cannulation of arterial and venous central blood vessels, etc.The price list of medical services for anesthesia was prescribed by the RHIF Council in Belgrade in 1990[9].The prices of services are annually aligned. The same anesthetic services as in 2006 were in 2015 calculated according to the Nomenclature and Price List of health services at the secondary and tertiary level of health care, which has been in place since 2014[10].

Personnel expenses were calculated as the sum of the gross amount of personal income of employees for an indefinite period, annually, in relation to anesthesiologist with 40 hours of overtime and anesthetist with secondary and higher education without overtime (shift work). Personal expenses are fixed costs, because they are accounted for according to the "By-laws on coefficients for the calculation and payment of workers' salaries in the public services ' $[11,12]$. Costs of administrative functions, teaching, scientific and professional titles, continuous education and overtime work of nurses were not included in personal expenses. Personal incomes of anesthetists working part time weren't also calculated as well as doctors on specialization in anesthesiology with reanimatology and clinicians without specialization.

The cost of anesthetics and other drugs necessary for anesthesia were recorded according to the cost accounting anesthetic chart for each department of anesthesia CCS, and according to the relevant prices of the Pharmaceuticals and Supplies Service for 2006. For the year 2015, the data was calculated according to the computer software, popularly called 'clinical trials'. The drugs used in anesthesia were: general and local anesthetics, analgesics, analgesic and benzodiazepine antidotes, mice relaxants, adrenergic agents, blood substitute agents such as human albumin and gelatin polymerizes etc., solutions for intravenous administration (for parenteral nutrition, electrolyte imbalance correction, electrolyte replacement, osmotic diuresis, isotonic solutions), etc.

The material included endobronchial and other tubes for acquiring airway for artificial ventilation, aspiration catheters, sodiumlime, sponges, needles, gloves, ECG electrodes, patches, gauze, bandages, disinfectants, etc.

Analyzes necessary for anesthesia were: biochemical (blood count, glycaemia, urea, creatinine, electrolytes, and urine), hematological (blood group, prothrombin time, partial thromboplastin time, bleeding length), radiological (x-ray lung recording) and cardiologic (electrocardiogram).

The services of other departments were not included, such as cardiology, hematological examination, psychiatric consultation, etc.

Medical equipment or basic equipment used in anesthesia included: anesthesia apparatus, respirators, cardiorespiratory function monitors, defibrillators, bronchial aspirators, laryngoscopes, masks, intravenous pumps for intravenous administration of drugs, etc.

\section{RESULTS}

\section{General indicators of anesthetic and surgi- cal services}

Data on the number of patients undergoing surgery, the number of anesthetic services, the number of surgical procedures performed, and the length of stay in ICU, in 2006 and 2015 are given in Table 1 .

There is no statistically significant difference within the scope of services $(\mathrm{p}=$ 1,000), between 2006 and 2015 in hospital work. There is a statistically significant difference in the frequency of service categories 
within the scope of services in 2015 compared to $2006(p<0.001)$. The ratio of the number of surgical interventions to the number of persons in operation was 1.5 in 2006 and 1.3 in 2015.

The number and percentage of anesthetic services detailed in the methodology are shown in Table 2.

\begin{tabular}{|l|c|r|r|r|}
\hline \multirow{2}{*}{ Types of anesthetic services } & \multicolumn{2}{|c|}{2006} & \multicolumn{2}{c|}{2015} \\
\cline { 2 - 5 } & $\mathrm{n}$ & \multicolumn{1}{c|}{$\%$} & \multicolumn{1}{c|}{$\mathrm{n}$} & \multicolumn{1}{c|}{$\%$} \\
\hline General anesthesia & 33,187 & 47.00 & 26,279 & 56.00 \\
\hline Local anesthesia & 16,394 & 24.00 & 9,652 & 21.00 \\
\hline Anesthetic procedure & 20,614 & 29.00 & 11,004 & 23.00 \\
\hline Average & 70,195 & 100.00 & 46,935 & 100.00 \\
\hline
\end{tabular}

There is no statistically significant difference in the number of anesthetic services between 2006 and $2015(\mathrm{p}=0.109)$. There is a statistically significant difference in the percentage of general anesthesia, the number of local anesthesia, and the number of anesthetic procedures in 2015 compared to 2006. ( $\mathrm{p}<$ $0.001)$.

The average length of general anesthesia in maternal surgical clinics is shown in Table 3, from our published study[13] is shown in Table 3.

The average length of Hospital Stay in ICU, the responsibility of the anesthetist and average number of hospital days in the maternal surgical clinics is shown in the table (Table 4).

\begin{tabular}{|l|l|l|}
\hline Number & 2006 & 2015 \\
\hline Operated patients & 32,267 & 45,505 \\
\hline Anesthetic services & 70,195 & 46,935 \\
\hline Length of stay in ICU & 33,549 & 33,434 \\
\hline Surgical interventions & 46,738 & 60,228 \\
\hline
\end{tabular}

Table 1. Number of patients operated, anesthetic services, surgical interventions and length of stay in ICU for the observed period in CCS

Table 2. Number, percentage and type of anesthetic services in 2006 and 2015 carried out in CCS

\begin{tabular}{|l|r|}
\hline \multicolumn{1}{|c|}{ Department } & $\begin{array}{c}\text { Average } \\
\text { time }\end{array}$ \\
\hline Neurosurgery & 378.29 \\
\hline Cardiovascular Surgery & 262.58 \\
\hline Pulmonary Surgery & 210.00 \\
\hline Orthopedic Surgery and & 196.62 \\
\hline Traumatology & 157.43 \\
\hline Urology and Nephrology & 157.27 \\
\hline Emergence Center & 138.94 \\
\hline Otorhinolaryngology and & 140.32 \\
\hline Maxillofacial Surgery & 130.81 \\
\hline General Surgery & 118.76 \\
\hline Ophthalmology & 92.09 \\
\hline Gynecology and Obstetric & 82.39 \\
\hline Endocrinology & 51.93 \\
\hline Burns, Plastic and Reconstructive \\
\hline Surgery
\end{tabular}



\begin{tabular}{|c|c|}
\hline $\begin{array}{c}\text { Intensive } \\
\text { care }\end{array}$ & $\begin{array}{c}\text { Average } \\
\text { Length of } \\
\text { Hospital Stay }\end{array}$ \\
\hline
\end{tabular}

\begin{tabular}{|c|c|}
\hline $\begin{array}{c}\text { Intensive } \\
\text { care }\end{array}$ & $\begin{array}{c}\text { Average } \\
\text { Length of } \\
\text { Hospital Stay }\end{array}$ \\
\hline
\end{tabular}

Neurosurgery

33,187

47.00

26,279

56.00

Cardiovascular Surgery

16,394

24.00

9,652

21.00

Pulmonary Surgery

20,614

29.00

11,004

23.00

Orthopedic Surgery and Traumatology

16,394

24.00

9,652

21.00

20,614

29.00

Otorhinolaryngology and Maxillofacial

Surgery

General Surgery

16,394

Ophthalmology

Gynecology and Obstetric

Endocrinology

Burns, Plastic and Reconstructive Surgery

Average

\begin{tabular}{|r|r|r|r|}
\hline 16,394 & 24.00 & 9,652 & 21.00 \\
\hline 20,614 & 29.00 & 11,004 & 23.00 \\
\hline 16,394 & 24.00 & 9,652 & 21.00 \\
\hline 20,614 & 29.00 & 11,004 & 23.00 \\
\hline 16,394 & 24.00 & 9,652 & 21.00 \\
\hline 20,614 & 29.00 & 11,004 & 23.00 \\
\hline 70,195 & 100.00 & 46,935 & 100.00 \\
\hline
\end{tabular}

Table 3. Average time of general anesthesia in the minute in surgical specialties
Table 4. The avarage Lenght of hospital stay and Number of days in the IC and EC in 2006 et 2015 


\section{Direct costs}

The listed prices of anesthetic services are according to RHIF Price list $[9,10]$ in Table 5.The listed price examples are an illustration of the value of anesthetic services $[11,12]$.
There is a statistically significant difference in the percentage of direct cost categories in 2015 compared to $2006(\mathrm{p}<0.001)$.
Table 5. The cost or value of an anesthetic service by group of services
Table 6. The annual gross amount of personal income expressed in Euros

Average RSD exchange rate 30.06.2006:

1EUR $=84.9995$

Average RSD exchange rate 30.06.2015:

1EUR $=120.6042$

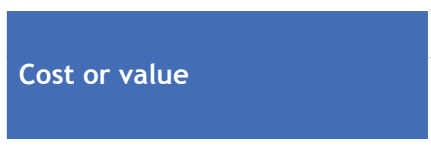

General anesthesia

\section{Local anesthesia}

Anesthetic procedure (sedation)

The annual gross amount of personal income of anesthesiologists and anesthetists is shown in Table 6.

\section{Personal income (annual gross amount)}

Anesthesiologist

Anesthetist with secondary education

Anesthetist with

higher education

A comparative analysis of the structure of direct costs of anesthetic and reanimatologic services for the years indicated is shown in Chart 1.

\begin{tabular}{|c|c|c|c|}
\hline \multicolumn{2}{|c|}{2006} & \multicolumn{2}{|c|}{2015} \\
\hline $\begin{array}{l}\text { Value in } \\
\text { u euros }\end{array}$ & $\begin{array}{c}\text { Length of } \\
\text { anesthesia }(\mathrm{min})\end{array}$ & $\begin{array}{l}\text { Value in } \\
\text { u euros }\end{array}$ & $\begin{array}{c}\text { Length of } \\
\text { anesthesia ( } \mathrm{min})\end{array}$ \\
\hline $\begin{array}{r}10 \\
(826 \text { RSD) }\end{array}$ & 60 & $\begin{array}{r}145 \\
(17,530 \text { RSD })\end{array}$ & 60 \\
\hline $\begin{array}{r}4 \\
(304 \text { RSD) }\end{array}$ & Local infiltration & $\begin{array}{r}9 \\
(1,030 \text { RSD })\end{array}$ & Local infiltration \\
\hline $\begin{array}{r}6 \\
(468 \text { RSD) }\end{array}$ & 30 & $\begin{array}{r}23 \\
(2,810 \text { RSD })\end{array}$ & 30 \\
\hline
\end{tabular}

\section{DISCUSSION}

Direct costs also affect the organization and management of the Center for Anesthesiology and Reanimatology. The Center for Anesthesiology and Reanimatology service provide its services in departments of anesthesiology and reanimatology through the Department of Anesthesiology and Reanimatology in Maternity (local) Surgical Clinics.The anesthesiologist is responsible for the treatment of patients in the Emergency Center and ICU in the maternal surgical clinics along with a surgeon who is responsible for surgical complications.

Anesthesiologists and anesthetists are engaged in operating rooms, ICU in Emergency Center, and are part of the team in ICU

Chart 1. Structure of direct costs of anesthesiologic and reanimatologic services

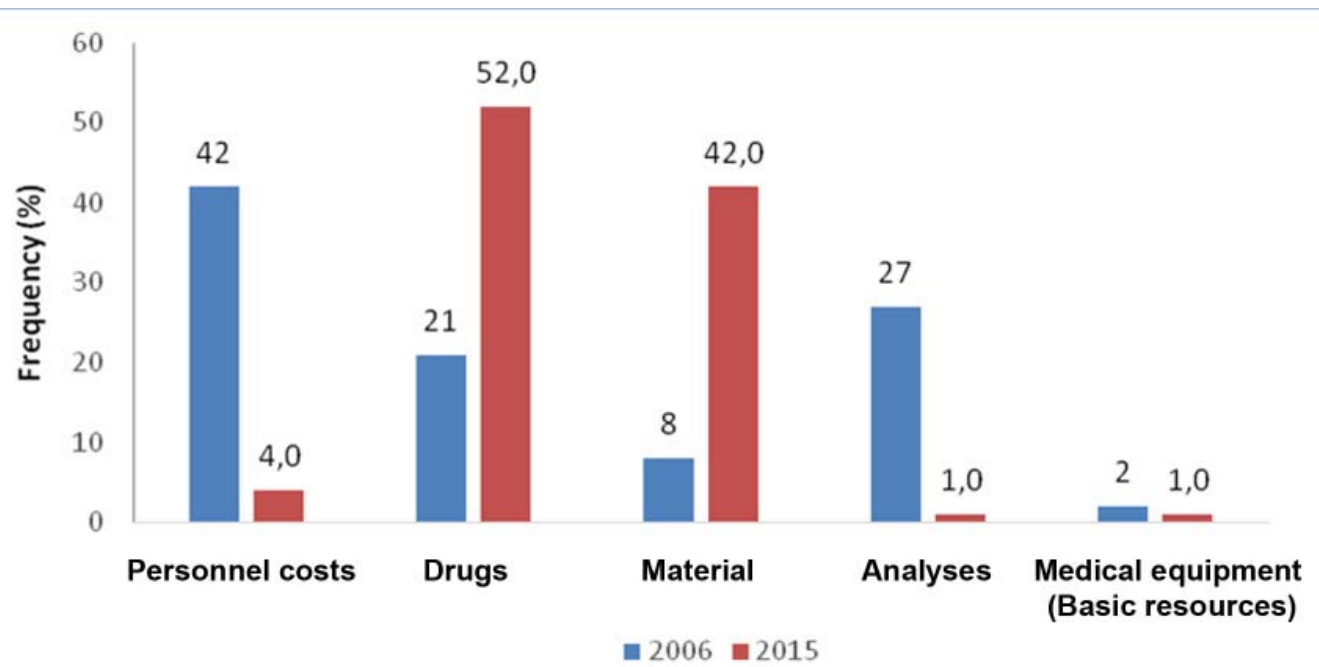

There is a statistically significant difference in total direct costs between 2006 and 2015 ( $\mathrm{p}=$ 0.043). in other clinics. They are providing as well anesthetic services in the Reception Department and Reanimation Clinic of the Emergency 
Center, Polyclinics, Departments for Pain Treatment at the Clinic for Digestive Surgery and in the Clinic for Urology and Respiratory Support at the Clinic for Pulmonology.They participate in the work of many medical departments in support of numerous diagnostic procedures and small surgical interventions. The Center has three main activities: education, science and health. Information systems have been introduced in Clinical Medicine and Healthcare Information System in 2013.

CCS is the institution of tertiary health care. It has a total of 41 organizational units: 23 clinics of which 11 belong to surgical activity, 9 centers one of which is Emergency Center, Polyclinic, and 9 Service Departments. In the CCS annually more than 90.000 patients are treated, more than 950.000 hospital days of treatment are achieved and more than 60.000 operations are performed. Hospital mortality ranged around 3.5\% for surgical activities[7]. Overall indicators of efficacy, quality and scope of hospital work and scope ofwork of 2015 in relation to 2006 show statistically significant $(\mathrm{p}<0,001)$ increase in the number of patients undergoing surgery and a decrease in the number of anesthetic services for almost the same length of hospital stay in ICU (Table 1).These seemingly paradoxical data can be explained by the rationalization of all services and cases, since length of hospital stay in ICU remained almost the same for a statistically significant increase in the number of surgical interventions.

Differences in the cost of anesthesiology and reanimatology in various surgical specialties are not known enough. From our pharmacoeconomic study [13], we presented table 3 which represents the average length of general anesthesia in 2006. The longest general anesthesia was in the Clinic of Neurosurgery, the Cardiovascular Surgery Clinic and the Lung Surgery Clinic. Longer anesthesia generates higher costs.

Table 4 shows the average number of hospital stay in ICU and surgical clinics according to our earlier study of direct costs in anesthesia [13] in 2006 and 2015: 5 to 10 days for patients at the Cardiac Surgery Clinic, Clinic for Endocrinology, Ophthalmology Clinic and Gynecology and Obstetrics and in Emergency center 10 to 15 days for patients with general surgery, urology, plastic surgery, neurosurgery, clinics for otorhinolaryngology and maxillofacial surgery; as well as 20 days in Pulmonology Clinic and Orthopedic Clinic $[13,14]$. The analysis could raise the issue of rationalization of costs in the Clinic for Urology and Nephrology and the Clinic for Burns and Reconstructive Surgery. The issue of legal regulation, networking and quality of work of regional hospitals and institutions of social health care would be raised, in modern conditions of health care.

Operations carried out in the Emergency Center are considered as emergency operations. Emergency operations accounted for $16 \%$ of the total, while $84 \%$ represent elective or planned operations, and the team of anesthesia, 2006. In 2015, according to the site CCS [7], there were $10 \%$ emergency surgeries and anesthesia in the Emergency Center compared to $90 \%$ in the local surgical clinics. The average length of treatment was 8 or 9 days in maternity clinics and 6 to 9 days in the Emergency Center during 2015. Daily hospitals were established in maternity surgical clinics for less, planned interventions. This logically led to fewer realized hospital days.

Based on the above, we would add that the efficiency and quality of hospital work is better. All this is explained by the more precise nomenclature of anesthesiologic services, accompanying developmental changes in health and technology, a type of modern methods of diagnostic and therapeutic, less invasive surgical procedures. There is a dilemma whether the nomenclature of health services at the secondary and tertiary levels of health care is precise, due to the large difference in the number of persons undergoing surgery (anesthetized) and the number of surgical interventions. The number of surgeries per surgical patient was 1.5 , while 10 years later it was 1,3 [7]. With a dull respect to the surgical profession, an inaccurate administrative record of services was noticed.The data obtained on the total number of general anesthesia for emergency surgery [14] from our earlier studies [15, 16 ] are in accordance with the literature data indicating that $10-20 \%$ of surgeries or anesthesia is considered to be an emergency $[17,18]$. Emergency surgery and anesthesia consume more funds than planned interventions.

The average length of treatment for both operated and anesthetized patients, the level of bed occupancy and other listed variables of quality measurement and efficiency of hospital work are not complete enough to assess anesthesia work. Our comparative analy- 
sis gives an example of methodological dilemmas that have yet to be solved. The work of an anesthesiologist starts from secondary health care and patients are not received because of anesthesia, but for surgical treatment. Direct reception through the reanimation ambulance includes vitally endangered surgical patients, when conducted according to the implemented diagnostic methods directly into the operating room, the ICU Emergency Center or hospitalization in the ICU maternity surgical clinic for the purpose of stabilizing the general state.Patient's hospital day in ICU varies by cost depending on the type of surgical specialty. Economically, costs of hospital day belong to the total cost of surgical activities. The total costs are also calculated by the loss of personal income due to illness, disability or death. We consider that due to the most frequent single use of anesthesia, all other services outside of the surgery and ICU are neglected or fiscally attributed to the surgical activity. For this reason, we have shown precise data on the average number of days of surgical and anesthetized patients in ICU and then gave up on continuing to follow these data. More precise databases of anesthesia associated with precise surgical databases would provide accurate information on the volume and value of these services $[19,20]$.

Our research on direct costs (Graph 1) showed that there was a statistically significant difference in total direct costs between 2006 and $2015(p=0.043)$. There is a statistically significant difference in the frequency of categories of direct costs in 2015 compared to $2006(\mathrm{p}<0.001)$.

Personnel costs were $42 \%$ for the period of research in 2006, while later personnel costs were $4 \%$ or ten times less spending per month. In 2014, two laws have been published with a view to the financial consolidation of the state budget, giving a framework for reducing pensions and salaries in the public sector [21]. Due to the mixed model of the organization of health care and in the meantime introduced legal provisions, we did not dare to comment on the changes we made. The methodology for calculating personnel costs is the same, according to the Decree on the Coefficient for auditing and Paying Salaries for Public Service Employees [11, 12]. Therefore, we believe that the obtained data are real. Other studies in 2005 and 2006 show that the personal costs of anesthesiologists, without medi- cal technicians, account for $30 \%$ of direct costs [22]. Comparing reduction of personnel costs with other countries is not realistic because of the different methodology of paying personal income such as: for performance, through the list of defined patients, based on salary grades, legal provisions, etc. The resulting difference in the value of direct costs of anesthesiology and reanimatology, is explained by doubling the cost of medicines and four times more funds allocated for material expenditures at the time of the country's exit from the recession, in the context of limited funds for health expenditures. The resulting difference in the value of direct costs of anesthesiology and reanimatology, is explained by doubling the cost of medicines and four times more funds allocated for material expenditures at the time of the country's coming out of the recession, in the context of limited funds for health expenditures.

Drug consumption increased from $21 \%$ in 2006 to $52 \%$ in 2015 . From anesthetics and other drugs used in anesthesia, the most expensive are as for price inhalation anesthetics and muscle relaxants, followed by general anesthetics (propofol) and solutions for intravenous administration. A study at the CCS [6] level showed that medication at the total direct costs of all internist, infectious, surgical and other institutes and clinics accounted for $15.46 \%$ of total costs in 2006. Anesthetics and other drugs in our study accounted 5.93\% of the total funds for medicines in CCS [14, $23,24]$. The data obtained were in agreement with other studies, where $5 \%$ of the total drug medication for the anesthesia hospital was 5\% [25]. General and local anesthetics, muscle relaxants and i. v. solutions, as well as some other drugs, do not have established DDD and it is recommended that the alternative route of data presentation in unit doses (UD-unit doses) or individual doses [26]. Some of the characteristics of anesthetics and other drugs used in anesthesia are: single use, simultaneous use of several groups of strong effects, different individual doses of the same drug (introduction and maintenance of anesthesia), exclusively using intravenous or inhalational anesthetics, and continuous intravenous administration of anesthetics,muscle relaxants or other drugs via Infusion pumpetc. The same drugs can be used preoperatively, operatively and postoperatively. The ability to preserve dissolved drugs is limited. 
The medication cost obtained in 2015 is explained by the increase in the number of medicines, including the antibiotics, the preparations for parenteral and oral nutrition, blood derivatives, etc., in the intensive care of surgical clinics and in the Emergency Center. The question remains whether the same department needs, applies, and fiscal dilates the drug.

The difference in the cost of basic assets needed for anesthesia, expressed in percentages (Table 7), was due to the difference in the number and cost of the analyzes but it leads to doubting the accuracy and precision of the obtained data. Health centers have laboratories for analyzes of planned surgery, but due to the use of a long list of waiting or changes in the order of urgent interventions, they are not always able to perform analyzes. From the second half of the past century, biochemical and hematological analyzes are performed in healthy and sick patients for pre-planned and urgent surgical interventions in order to reduce the risk of operative and postoperative comorbidity and mortality [27]. Harmonized opinion on routine or standard analyzes for elective interventions is not yet reached, therefore, they are at the level of recommendation. Pharmacoeconomic studies agree that the analysis is performed in each patient with a comorbidity.

Medical equipment for basic anesthesia was insufficient in all periods of our research. For example, depreciation value of anesthetic apparatus loses virtually any value after five years of use. The methodology of auditing fixed assets is not well resolved neither in our literature nor in foreign literature [28].

Ten years later, direct costs showed that the share of personnel costs decreased and part of the cost of materials and medicines increased, due to changes in the fiscal turnover, more precise but still insufficiently precise application of the Nomenclature and Price List of Health Services at the secondary and tertiary level of health care and due to organizational changes in CCS. In modern medicine treatment is a multidisciplinary process in which doctors of various specialties participate in team work.

The direct costs of anesthesia vary depending on the following: general condition of the patient, the degree of urgency, the type and technique of anesthesia and anesthetic procedures, personal expenses, consumed anesthetics and other drugs necessary for the application of anesthesia and / or reanimation, costs of medical and non-medical materials. The time required for the delivery of services, utility of drugs and the number of hospital days in ICU are parameters that increase direct costs. Little is known about the direct costs of anesthesiology and reanimatology in various surgical specialties, and in Table 4 we gave data indicating an unjustified large number of hospital days, a long preoperative preparation, and a longer unplanned waiting period for planned interventions $[18,22]$.

The economic construction of anesthetic work was previously based on the number and length of anesthesia for surgery, in the traditional system of cost auditing. Expenses of anesthesiology have been interpreted since 1990 as a cost of clinical support [13] to surgery as the center of clinical consumption. For the year 2006, the cost of anesthesia would increase the cost of surgery by $10 \%[6,13,29]$. We did not have the available data for 2015 .

To add, the basic principles of asset rationalization include: identification of direct costs, their analysis and the implementation of pharmacoeconomic analyzes.Drugs, medical, non-medical materials and medical equipment are concrete costs because they have to be purchased from the pharmaceutical industry and other medical industries [29]. Theoretically, there is scope for rationalization, but it is not possible to limit only the choice of anesthetics, without reducing the costs of the pharmaceutical and technological industry. All other items of direct costs are contractual. A posh rigid bureaucratic hospital administration might be interested in reducing costs with more efficient work. The profession is developing and lately, the process of treatment poses new challenges of management, where time and resources are limiting factors. Leaving aside the methodological dilemma [30] and our intention to provide the scope, the distribution and the value of anesthetic work in the economic, geopolitical and cultural framework of the health system of Serbia and beyond, it is likely that the best quality of medical service today would prove less costly and cheaper in the future [31].

These data are from the largest health center of the tertiary level of health care in Serbia. The authors consider the necessary and useful implementation of multicenter academic studies with the participation of several 
countries in Europe so that doctors can get a glimpse into the comparative factual state of the anesthesiology business of several countries, the possibilities of correction and the support of evidence based medicine to more easily achieve the required standard in this specialist field of clinical medicine [32].

\section{CONCLUSION}

The general indicators of the efficiency and quality of hospital work and workload, 2015 compared to 2006, show that a statistically significant $(p<0.001)$ increase in the number of patients and surgical interventions has been achieved, while reducing the number of anesthetic services for almost the same length of hospital days in ICU, while reducing the percentage of emergency surgery and anesthesia, as well as reducing the average length of hospital treatment. Based on the following facts, it can be concluded that:

1. The 10-fold decrease in personnel costs in the 2015 statistics is certainly not a consequence of a change in the methodology, but a constant, chronic and progressive impairment of vocational work in total health care costs;

2. Anesthetist services are only visible during their stay in the operating room. It is evident that most of the services performed in: preoperative assessment and preparation, immediate postoperative and delayed, chronic treatment of critical patients, are either unrecognized or incorrectly attributed to surgical specialties;

3. The quality of the statistical data presented is indicating the lack of interest of the hospital administration in analyzing and utilizing the collected data in reducing and rationalizing health care costs;

4. Academic multicenter studies in pharmacoeconomics are needed to help doctors to achieve a better uniform standards of providing anesthesia services using evidence based medicine.

\section{REFERENCES}

1. The International Surgical Outcomes Study group. Global patient outcomes after elective surgery: prospective cohort study in 27 low-, middle- and high-income countries. British Journal of Anaesthesia 2016; 117(5):601-9.

2. Chao JJ, Cales-Black J, Chuen J, Weinberg L, Rachbuch C. The application of three-dimensional printing technology in anaesthesia-a systematic Review. Anaesthesia 2017; 72(5):641-650.
3. Jakovljević M, Getzen TE. Growth of Global Health Spending Share in Low and Middle Income Countries. Fron Pharmacol 2016; 7:21.

4. Rowe WL. Economics and anaesthesia. Anaesthesia 1998; 53:782-788.

5. European Parliament and the Council of the European Union Directive 2001/20/EC of the European Parliament and of the Council of 4 April 2001 on the approximation of the laws, regulations and administrative provisions of the Member States relating to the implementation of good clinical practice in the conduct of clinical trials on medicinal products for human use (Clinical Trials Directive). Available from: http://www.eortc.be/services/Doc/clinicalEU-directive-04-april-01.pdf.

6. TA for Capacity Building for Tertiary Care Services Republic of Serbia. A project funded by the European Union. Belgrade: Ministry of Health of the Republic of Serbia, Europian Investment Bank / Sofreco; 2006.

7. Informator o radu Kliničkog centra Srbije. Informer of the Clinical Centre of Serbia work. (on Serbian) ( www.kcs.rs/index.php/informator-oradu )

8. Pravilnik o pokazateljima kvaliteta zdravstvene zaštite u Srbiji. Regulations of Indicators of Quality of Health Care in Serbia. (on Serbian) www.batut. org.rs/.../Pravilnik\%200\%20pokazateljima\%20 kvaliteta\%20zdravstvene\%.

9. Odluka o zajednićkim kriterijumima i merilima za utvrdjivanje cena zdravstvenih usluga.Službeni glasnik Republike Srbije3/91. Decision on common criteria and measures of setting price-list of health service. Official Gazette of the Republic of Serbia 3/91.(on Serbian) www.rfzo.rs/.../

10. Nomenklatura i cenovnik zdravstvenih usluga na sekundarnom I tercijalnom nivou zdravstvene zaštite. Službeni glasnik Republike Srbije 37/2014. Nomenclature and price list of health services at the secondary and tertiary level of health care. Official Gazette of the Republic of Serbia 37/2014. (on Serbian) www.rfzo.rs/.../Nomenklatura\%20 zdravstvenih\%20usluga\%20na\%20sekundarnom\%...

11. Uredba o koeficijentu za obračun i isplatu plata zaposlenih u javnim službama.Službeni glasnik Republike Srbije 106/2006). By-laws on coefficients for the calculation and payment of workers' salaries in the public services. Official Gazette of the Republic of Serbia 106/2006. (on Serbian). www.minrzs. gov.rs/.../Uredba\%20o\%20koeficijentima\%20za\%20 obracun\%20plata

12. Uredba o koeficijentu za obračun $i$ isplatu plata zaposlenih u javnim službama. Službeni glasnik Republike Srbije 79/2009. By-laws on coefficients for the calculation and payment of workers' salaries in the public services. Official Gazette of the Republic of Serbia 79/2009. (on Serbian). www.minrzs. gov.rs/.../Uredba\%20o\%20koeficijentima\%20za\%20 obracun\%20plata 
13. Majstorović BM, Vučović DS, Milaković BD, Mikov MM, Mijajlovic MS, Markovic SZ, Kastratović DA. The Analysis of Direct Costs in Anesthesia. Journal of Pharmacy Research. 2011; 4(10):3520-24. (www; pronline.info)

14. Majstorovic BM, Kastratovic DA, Vucovic DS, Milakovic BD, Milicic BR. Analiza operativnih troškova $\mathrm{u}$ anesteziji-ABC analiza.Operating Cost Analysis of Anaesthesia: Activity Based Costing (ABC Analysis). Srp Arh Celok Lek. 2011; 139(7-8):501-508. (on Serbian).

15. Majstorović BM,Kastratović DA, Vućović DS, Milaković BD, Gojković-Bukarica LČ, Pekmezović TD.Farmako ekonomska procena tro[kova u Anesteziologiji. Pharmaco-Economic Estimation of Cost in Anesthesiology. Pharmaca Serbica 2009;1(1.2):3640. (on Serbian)

16. Majstorovic BM, Simic S, Milakovic BD, Vučovic DS, Aleksic VV. Deskriptivna analiza rada i trendovi u anesteziiji 2005. i 2006. godine: kvantitativni i kvalitativni aspekti efekata i vrednovanja anestezije.Descriptive Analysis of Work and Trends in Aneaesthesiology from 2005 to 2006: Quantitative and Qualitative Aspects of Effects and Evaluation of Anaesthesia. Srp ArhCelok Lek.2010; 138(9-10):624631.(on Serbian)

17. Dhupar R, Evankovich J, Klune JR, Vargas LG, Hughes SJ. Delayed operating room availability significantly impacts the total hospital costs of an urgent surgical procedure. Surgery. 2011; 150(2): 299-305.

18. Schuster MA, Standl T, Thomas W, Joachim A, Berger J, Reimann H, et al. Effect of different cost drivers on cost per anesthesia minutes in different anesthesia subspecialties. Anesthesiology. 2004; 101(6):1435-43.

19. Negrini D, Kettle A, Sheppard L, Mills GH, Edbrooke DL. The cost of a hospital ward in Europe: Is there a methodology available to accurately measure the costs? Journal 2004; 18(3):195-206.

20. Majstorovic BM, Milaković BD, Marković SZ, Mijajlović MS, Kastratović DA. The Results and Methodological Concerns about Pharmaco-Economic Evaluation in Anesthesia. Hospital Pharmacology. 2014:1(2); 68-75. Hospital Pharmacology - International Multidisciplinary Journal (www.hophonline. org)

21. Zakon o privremenom uređivanju osnovica za obračun I isplatu plata, odnosno zarada I drugih stalnih primanja kod korisnika javnih sredstava. Službeni glasnik Republike Srbije 116/2014..Law on temporary regulation of the basis for the calculation and payment of salaries or wages and other regular income in public funds. Official Gazette of the Republic of Serbia 116/2014 (on Serbian).

22. Schuster MA, Standl T. Cost drivers in anesthesia: manpower, technique and other factors. Curr Opin Anesthesiol. 2006;19(2):177-84.

23. Majstorović BM, Kastratović DA, Milaković BD,
Marković SZ, Mijajlović MS, Vucović DS. Troškovi primene anestetika i drugih lekova u anesteziji. Cost of anesthetics and other drugs in anesthesia. Med Pregl. 2012; 65(1-2):30-4. (on Serbian).

24. Majstorović BM,Milaković BD,Kastratović DA,Milićić BR,Vucićević VR. Smanjenje direktnih troškova u anesteziji nije put za racionalizaciju anesteziološkig troškova. Reductions in anesthesia direct costs is not the right way for racionalization of anesthesia costs. Med Pregl.2012;65(9-10):421-7. (on Serbian).

25. Rinehardt EK, Sivarajan M. Costs and wastes in anesthesia care. Curr. Opin Anaesthesiol. 2012;25(2):221-5.

26. Jakovljevic V, Sabo A, Tomic Z. Drugs in circulation. In:Handbook of medicines and their use of ATC classification. Novi Sad: Ortomedics; 2009. str. 229-34.

27. Gyanendra K Sharma. Preoperative Testing: Owerview, Selective Workup, Summary. Medscape Sep 16, 2015. http://emedicine.medscape.com/ article/285191-overview

28. Majstorović BM, Vučović DS, Milaković BD, Kastratović DA, Gajić M. Anesteziološki rad, direktni, indirektni I ukupni troškovi anestezije I anestezioloških usluga 2006. godine u Institutu za neurohirurgiju Kliničkog centra Srbije. Anesthesiological work, direct, indirect and total costs of anesthesia and anesthetic services in 2006 at the Institute of Neurosurgery of the Clinical Center of Serbia. Anesthesia and intensive therapy. 2007; 30(2):71-9. (on Serbian).

29. Majstorovic BM, Milaković BD, Marković SZ, Mijajlović MS, Kastratović DA. The Results and Methodological Concerns about Pharmaco-Economic Evaluation in Anesthesia. Hospital Pharmacology. 2014:1(2); 68-75. Hospital Pharmacology - International Multidisciplinary Journal (www.hophonline. org)

30. Majstorović BM, Milaković BD. Anesthetic Services in Serbia. Hospital Pharmacology. 2016; 3(1):361369. Hospital Pharmacology - International Multidisciplinary Journal (www.hophonline.org)

31. Majstorović BM, Milaković BD, Marković SZ, Kastratović DA. Anesthesia Today With the Economic and Clinical Aspects. Hospital Pharmacology. 2016; 3(2):402-408. Hospital Pharmacology - International Multidisciplinary Journal (www.hophonline.org)

32. Marković SZ,Kastratović DA, Kubiak C, Demotes Mainard J. ECRIN - Needed in European Science. Hospital Pharmacology. 2015; 2(2):279-282. Hospital Pharmacology - International Multidisciplinary Journal (www.hophonline.org ) 


\title{
Studija direktnih troškova u anesteziologiji i reanimatologiji u Kliničkom centru Srbije
}

\author{
Branislava M. Majstorović ${ }^{1}$, Branko D. Milaković1,6, Tamara S. Naumović ${ }^{2}$, \\ Zoran M. Bukumirić ${ }^{3}$, Srdjan Z. Markovićc ${ }^{4}$ Dragana A. Kastratović, \\ Ivan D. Vukašinovićs ${ }^{5}$ Nebojša G. Ladjevićc ${ }^{1,6}$ \\ ${ }^{1}$ Centar za anesteziologiju i reanimatologiju, Klinički centar Srbije, Beograd, Srbija \\ ${ }^{2}$ Institut za javno zdravlje Srbije, "Dr Milan Jovanović Batut”, Beograd, Srbija \\ ${ }^{3}$ Institut za medicinsku statistiku i informatiku, Medicinski fakultet Univerziteta u Beogradu \\ ${ }^{4}$ Klinički centar Srbije, Beograd, Srbija \\ ${ }^{5}$ Kabinet za interventnu i invazivnu neuroradiologiju, Centar za radiologiju i magnetnu rezonancu, \\ Klinički centar Srbije, Beograd, Srbija \\ ${ }^{6}$ Medicinski fakultet, Univerzitet u Beogradu, Beograd, Srbija
}

\section{KRATAK SADRŽAJ}

Uvod: Savremena zdravstvena zaštita podrazumeva kontiunirani razvoj humanih resursa i primenu farmakoekonomskih analiza tokom uvođenja novih metoda lečenja u medicini.

Cilj: Cilj rada je komparacija i analiza: 1) broja: operisanih bolesnika, anestezioloških usluga, bolničkih dana (b.o. dana) u JIL i hirurških intervencija; 2) raspodele anestezioloških usluga: opštih anestezije, lokalnih anestezija i anestezioloških procedura; 3) vrednosti direktnih troškova anesteziologije i reanimatologije u 2006 i 2015 kako bi se predložile mere racionalizacije i uštede sredstava.

Metodologija: Ovaj rad je akademska, studija preseka IV faze usklađena sa direktivama Evropske Unije uz dozvolu Etičkog komiteta Medicinskog fakulteta Univerziteta u Beogradu. Računati su i analizirani direktni troškovi anestezioloških usluga Centra za anesteziologiju i reanimatologiju, po odeljenjima anestezije u matičnim hirurškim klinikama Kliničkog centra Srbije u Beogradu, tokom 2006 i 2015 godine. Ispitanici su bili svi anestezirani bolesnici, oba pola, deca i odrasli. Numerički podaci su obrađeni kompjuterskim programima Microsoft Office Excel 2003 I SPSS for Windows. Za analizu statističke značajnosti broja operisanih bolesnika, anestezioloških usluga, bolničkih dana u Jedinicama intenzivnog lečenja i hirurških intervencija koriščen je Wilcoxov test. Za analizu procentualne zastupljenosti sredstava u učestalosti kategorije direktnih troškova (personalni troškovi, lekovi, materijal, analize i medicinska oprema), u 2015 godini u odnosu na 2006 godinu, korišćen je hi-kvadrat test slaganja.

Rezultati: Postoji statistički značajna razlika u učestalosti kategorija usluga unutar obima usluga u 2015 u odnosu na 2006 godinu( $(p<0,001)$, pokazateljima bolničkog rada.

Postoji statistički značajna razlika u učestalosti vrsta anestezioloških usluga u 2015 u odnosu na 2006 godinu $(p<0,001)$.

Postoji statistički značajna razlika u ukupnim direktnim troškovima anesteziologije i reanimatologije između 2006 i 2015 godine $(p=0,043)$. Postoji statistički značajna razlika u učestalosti kategorija direktnih troškova u 2015 u odnosu na 2006 godinu $(p<0,001)$. $\mathrm{U}$ periodu recesije i tranzicije 2006 godine, za personalne troškove se odvajalo $42 \%$ sredstava, za lekove i materijal 29\%, analize i medicinske aparate $29 \%$. Direktni troškovi anestezioloških usluga bi na godišnjem nivou bili $10 \%$ u odnosu na sredstva hirurške delatnosti. Ne uzimajući u obzir metodološke nedoumice (organizacione promene, uvođenja novih grupa lekova u odgovornost anesteziologa, ograničavajućih zakonskih uredbi, viših cena), posle desetogodišnjeg perioda, odnos direktnih troškova je promenjen u 2015, tako da personalni troškovi čine 4\%, lekovi i materijal 94\%, ana- 
tize i medicinska oprema $2 \%$.

Zaključak: Opšti pokazatelji efikasnosti i kvaliteta bolničkog rada i obima rada, 2015 u odnosu na 2006 godinu, pokazuju da je došlo do statistički značajnog $(p<0,001)$ povećanja broja operisanih bolesnika i hirurških intervencija uz smanjenje broja anestezioloških usluga za skoro isti broj b.o. dana u JIL, uz istovremeno smanjenje procenta hitnih operacija i anestezija, kao i smanjenjenje prosečne dužine bolničkog lečenja.Na osnovu navedenog bi dodali da je efikasnost I kvalitet bolničkog rada bolji.

1.Desetostruko smanjenje personalnih troškova, u statistici 2015 godine, sigurno nije samo posledica promene metodologije, već i konstantnog, hroničnog i progresivnog obezvređivanja strukovnog rada u ukupnim troškovima zdravstvene zaštite.

2. Usluge anesteziologa vidljive su samo tokom boravka u operacionoj Sali. Evidentno je da veći deo usluga koji se obavlja u: preoperativnoj proceni i pripremi, neposrednom postoperativnom i odloženom, hroničnom lečenju kritičnih bolesnika, biva ili neprepoznat ili pogrešno pripisan hirurškoj specijalnosti.

3. Kvalitet statističkih podataka koji su prezentovani ukazuje na nezainteresovanost bolničke administracije za analizu $i$ iskorišćavanje sakupljenih podataka u smanjenju i racionalizaciji troškova zdravstvene zaštite.

4. Potrebne su akademske multicentricne studije iz farmakoekonomije koje ce lekarima pomoci da ostvare bolji ujednacen standard pruzanja anestezioloske usluge koristeci evidence based medicine.

Ključne reči: anesteziologija i reanimatologija, bolnička farmakologija, farmakoekonomija, direktni troškovi 